\title{
HET FILOSOFIE EN VAKFILOSOFIE ENIGE BETEKENIS VIR BEROEPSOPLEIDING?
}

\author{
J.J. VENTER, Dept. Fïlosofie, Fort Hare
}

\begin{abstract}
ABSTRAC.".
In the light of increasing professionalism and utilitarianism in university training the philosophers and the subject philosophers have the responsibility to indicate the relevance of their fields of endeavour within the framework of. training for the professions. The author points out the contribution of these subjects towards the undeniable intellectual inrichment and power of judgement by reference to two professions, viz. those of business manager and of medical doctor. By being professionally supportive Philosophy and subject philosophies can be strengthened by supporting amongst others neglected or under-developed professions by means of a professional philosophy. The fact that the professional world teems with philosophical problems should be brought home not only to colleagues in professional training institutions bul also to those who have influence in the professional roorld itself.
\end{abstract}

1)at ons byeenkom om oor die betekenis van die filosofiese vakrigtings te praat, toon iets van die moeilike posisie waarin die Filosofie verkeer. I)ie vraag of Filosolie en vakfilosofie enige relevansie vir die beroepsteiding het, is vir die filosoof eint lik maar'n retoriese vraag: hy twyfel nie daaraan dat sy vak daardie betekenis besit nie. Hy is egter verplig om die hele saak in vraagvorm as 'n besprekingsprobleem aan te bied om die gedagtes van sy kollegas hieromerent te probeer loswoel, want vir hulle blyk die belang van die bilosofie telkens ver van duidelik te wees.

Met die voortgang van professionalisering in die samelewing en die groeiende teen woordigheid van beroepsopleiding aan die universiteit word die situasie van die filosoliese vakrigtings steeds moeiliker, omdat hulle vermoé om studente te trek sterk anhanklik is van die mate waarin die dosente in die professionele rigtings die belang van Filosolie insien (of nie insien nie) en hulle studente aan-of afraai om lilosofie in hulle leergange in te sluit. Ons kan met veiligheid sê dat die meerderheid dosente in die beroepsopleidingsrigtings Filosolie as 'n nuttelose vak beskou.

Daar is meerdere weet waarlangs die lilosoof hom uit hierdie situasie kan loswikkel. 1)ie cerste is om saam met sy kollegas uit die basiese wetenskappe 'n georganiseerde verset teen die groeiende prolessionalisme en utilisme in die universiteitsopleiding van stapel te stuur, in die hoop dat die

Koern, 47(2) 1982 


\section{Venter}

aanswellende stroom gekeer kan word. ' $\mathrm{n} A$ nder is om dic betekenis van ons vakgcbied te probeer duidelik maak - miskien, wic weet, mag Filosolic dan ' $\mathrm{n}$ aantreklike keusevak vir die beroepsrigtings word. My eic strategic is om die eerste te doen maar veral die tweede nie na te laat nie.

Die ecrste paadjic lyk, vanuit die "wese" van die universiteit gesien, na die weg wat die voorrang verdien. 'n Universiteit is immers ' $n$ inrigting wat as taak het die opleiding van vaklecrlingwetenskaplikes tot selfstandige wetenskapsbeoefenaars deur hulle aan dic wetenskapsproses te laat deelneem. 'n Vergroting van dic beroepsoplcidingskomponent lyk na 'n bedreiging van die "wese" van die universiteit; daarom, so redencer ons dan, moet ons dit gekoördineerd in rade en komitees van die universiteit teenstaan in belang van die universiteit as sodanig en ter beskerming van ons eic vakgebiede, wat al verder na die populariteitsperiferic gestoot word. Hoewel dit waar is dat die groci in beroepsopleiding in sy (ekstreem) professionalistiese en utilistiese gestaltes inderdaad ernstige gevare vir die universiteit, "basiese" wetenskappe en wysgerige vakrigtings inhou, volg nogtans nie hieruit dat die voorgestelde verset inderdaad 'n doeltreffende beskerming teen dic gevare bied nie - in die verlede het dit slegs beperkte sukses opgelewer, en in die toekoms sal dit hoogs waarskynlik stceds minder geslaagd wees vanweë' $n$ verskeidenheid drukfaktore wat eenvoudig vir ons te sterk is, waarvan ek slegs enkeles noem:

Wêreldwyd, ecrstens, het 'n vertegnisering en verwetenskapliking van die kultuur hom reeds in gevorderde mate voltrek (vgl. bv. Van Riessen, 1971 en Esterhuyse, 1975) - maar dit wect ons almal reeds. Hierdic kultuurverandering het regstrecks te make met die geweldige strewe na nut, wat reeds sedert 'n paar ecue tot 'n kernwaarde van die Westerse denkpatroon verhel is. (Vgl. bv. Goudzwaard, 1976:33 e.v.; Esterhuysc, 1975: l e.v.). Dic uitvloeisel van hierdie kulturele neiging is om enige studierigting wat nic onmiddellik sy betekenis vir die tegnologie (vir sover dit die produksic van ver(lere nuttighede sal bevorder) kan aantoon nie, as onbelangrik te beskou. Om die vertegniseerde, verwetenskaplikte samelewing se ratte aan die draai te hou vere is hoog geskoolde natuurwetenskaplikes, ingenieurs en bestuurders (asook maatskaplike werkers en psigiaters) om die ratte waarvan die asse breek, weer in die stelsel teruggeplaas te kry. Die universiteit word vanuit hicrdic samelewing gesien as 'n produksiemiddel wat dic investering in hom moet goed maak deur die allewering van bruikbare nntsprodusente (vgl. bv. Kerr, 1963.) 
Filosofie en beroepsopleiding

Ons eie. land is nog nie so ver op tegnies- wet enskaplike weg gevorder nie. In ons geval is dit egter nie 'n besondere voordeel nie, omdat ons in 'n maatskaplike noodsituasic verkeer wat ons in ieder geval in dicselfice rigting dwing. Die geweldige aan was van ons bevolking en die toenemende militêre eise waarvoor ons te staan kom, vercis dat ons 'n hoë ontwikkelingstempo moet handhaaf om ons mense te kan voed, sinvol besig te hou en die vrede te bewaar. Die onverstandige wyse waarop ons die veclvolkigheid van ons land polities gehanteer het, het dic posisie nog verder lemocilik: dekades van terughouding van die. Swartman tesame met die bevolkingsontplolling het ons in dic situasie gebring dat ons tot die jaar 2000 gemiddeld cen cluisend werkgcleenthede per dag moet skep maar nie oor dic infrastruktuur aan geskoolde mannckrag beskik om die topposte, wat vir werkgelecntheidskepping noodsaaklik is, te kan vul nic. 'n Positic we brleid vant werkgrlecntheidskcpping is egter nodig, omdat ekonomiese groci as sodanig allecn nir genoeg is om dic vraagstukke van werkloosheid, armoede en inkomeverspreiding dic hoof te bicd nic (vgl. verder Spies, 1979:2-3). Dic gebrek aan geskoolde mannekrag bring 'n dreinering van dic onderwysberoepe mee, wat weer die ontwikkeling vertraag. Die aantal Swart gematrikulecrdes verdubbel weliswaar elke jaar, maar die kwaliteit van hulle skoolopleiding is so swak dat vir huille in ieder geval 'n vorm van tersiere beroepsopleirling benolig word on hulle min ol' meer bruikbaar in diens gestel te kry.

Een van dic Icsse van ontwikkelingswerk in dir dercle wêreld is dat ont wikkelingskapilaal net in die mate geabsorbeer kan word wat daar reeds mannckragbrome in die hooggeskoolde beroepe (d.w.s. bestuurders, ingenieurs, wetcnskaplik gevormde politici, universitcitsdosente en onclerwyscrs) en die middelvlak (d.w.s. tegnici, klerke ens) ontwikkel is (vgl. (iimblerg, 1971:14; ook Inesco 1963:41, 58 e.v. en Bushnell, 1967:187 c.v.). Ons kan die mindergeskoolde unense van ons land nie oplief as ons nie die geskooldheid aansienlik verhoog nic. I)aarom sal die druk op ons universiteite om meer mense beroepsgeskoold af te lewer vinnig verhoog en waarskynlik ook slaag, want as dic universiteite nie 'n bepaalde mate claarvan teckee nic, sal die samelewing sy steun eerder aan alternatiewe, beroepsgerigle inrigt ings gee in die woorde van' 'n groot voorstander van die volledige professionalisering van universiteitsople idling: "I The cost of providing a university education... is met by a socicty and it has every right to expert that that great cost will result in an even greater benefit to it. If the society does not benefit from its investment in a university, it should close the university, cut its losses and invest elsewhere". (J.B. ( Gardiner, Dirertor of Extronal Studies at (IFH, 1981:4). Die tendens on miversiteite volledig berocpsgerig in te rig is besig om vlees te word in die Iniversiteit van 


\section{Venter}

Bophuthatswana en die Universiteit Vista. (Ook die De I angekommissie frons oor die "akademiese" waardesisteem in die Suid-Afrikaanse skoolopleiding (d.w.s. die universiteitsgerigtheid van ons skoolstelsel) (HRSC, 1981:31), en dit is te verwagte dat steeds groter getalle leerlinge in die nabye toekoms reeds op skool in een of ander beroepsrigting sal spesialiseer.

Kortom: die tendense dui aan dat lilosowe, vakfilosowe en "basiese" wetenskaplikes die tweede weg in hierdie stadium besondere klem moet laat kry in die aangesig van die feit dat steeds meer en meer beroepskursusse hulle verskyning aan die universiteit gaan maak. Ook as die tolale strategie nie lundamentcel verander nie, moel ons nogtans ons taktiek verander en die uitdaging aanvaar on die betekenis van ons vakgebiede vir die beroepslewe en die opleiding daarvoor aan te toon. Besien vanuit die algemene eise wat die beroepslewe self aan beroepsopleiding stel, is hierdie taak minder moeilik as wat dit op die oog af mag lyk. Ons argumente vanuit die algemene eise kan aangevul word met' $n$ analise van die spesifieke eise vir bepaalde beroepe, waaruit al gou sal blyk dal Filosolie 'n belangrike komponent van die beroepslewe self is en claarom in die opleiding eksplisiete. en vakkundige aandag verdien. Wil ons hieraan uitvoering gee, mag ons egter telkens weer verhinder word deur hardnek kige vooroordele en roosteren leergangkomplikasies.

\section{I)E AICGEMENL EISE}

Dit is myns insiens moontlik om op basis van die algemene eise wat die beroepslewe aan die beroepsopleiding stel, te argumenteer dat die groei van beroepsopleiding aan die universiteit, indien reg gehanteer, nie noodwendig 'n bedreiging vir die "wese" van die universiteit en die wysgerige vakrigtings hoef in te hou nie; trouens, die posisie van Filosolie kan claardeur versterk word.

Die beroepsmense weet uil konkrele ervaring dat die tegniese vaardighede wat vir die beroepe vereis word, teen tien jaar na graduering reeds verouderd is (vgl. bv. Tyler, 1972:238). Die standhoudende deel van die student se opleiding bly dus die basies wetenskaplike elemente daarin. Daarom vind byvoorbeeld dr. F.P. Jacolss, 'n bekencle direkteur van maatskappye, dit nie mocilik om hom neer te lê by dic Van Wyk de Vrieskommissie se tipering van universiteitsopleiding as beroepsivorbereidend eerder as berocpsopleidend nie. Hy pleit egter wel vir 'n groter integrasie van universitêre opleiding en navorsing met die beroepspraktyk (vgl. Jacolssz, 1977:26, 28-30). 
Filosofie en beroepsopleiding

Die groot meerderheid van die universiteit se beroepsopleiding is bestem vir die professionele en semiprofessionele beroepe. Van hulle geld Tyler (1972:23I) se lipering: "The central tasks of profession are not performed by routine practice of accepted procedures. The problems the professional is expected to solve are complex and involve variations in conditions that make specilic rules too rigid to be effective. The professional is presumed to operate on the basis of artistic adaptations of general principles relevant to the problem faced". 'Ter wille van hierdie kreatiwiteit pleit Tyler dan vir 'n versterking van die interdissiplinêre aspekte van opleiding en professiebeoffening. Hiermee sou moontlik ook beter beant woord kan word aan die eise van ons tegnieswetenskaplike kultuur met sy sterk toekomsgerigtheid: "Typical of a science culture is its leaning towards the future. This implies that universities should stimulate ingenuity and creativity rather than merely kecp up traditional techniques and knowledge - which might, in any case, become obsolete within a short space of time. In present day society the student who displays ingenuity and creativity is better equipped to cope with rapidly changing situations than the one who is only textbook trained. This student is in danger of being relegated to the academic garbage pile, testbook and all" (Esterhuyse, 1977:271)

Saam met clie vordering van die universitêr opgeleidene, wat tot die hooggeskoolde en daarom meesal ook tot die leiersgroep in sy beroep behoort, verander sy verantwoordelikhede: dit verplig horn hoe langer hoe meer om op die basiese, die algemene en die filosofiese in sy opleiding terug te val: hy skuif naamlik geleidelik weg van die tegniese beroepsuitoefening na die beslıitnemende, van die vakmanskap na die adminisırateurskap of bestuurderskap - of, soos dr. Jacobsz dit stel: "Meeste van ons wat ons in die ny werheidswese bevind, het in een of ander gespesialiseerde beroep met ons loopbaan begin, maar dit het vir ons reeds gou duidelik geword dat namate ons opgang gemaak het, ons ininder gespesialiseerde werk gedoen het, sodat die lunksies wat ons verrig het, meer basies en algemeen van aard was. Die soort probleme waarmee gewerk word, vereis 'n breër algemene kennis, 'n insig in die sielkunde van die mens, en 'n helder clenkvermoë. Daar moet 'n groot mate van intellektuele groei plaasvind om die individu in staat te stel om alles te kan waarneem wat om hom aangaan. My standpunt is dat spesialisasie, alhoewel dit floreer in 'n laboratorium of navorsingsdepartement, op sigself 'n onvoldoende kwalifikasie vir uitvoerende bestuur is". 


\section{Venter}

Dr. Jacobsz (1977:25-26) huiwer nic om stroom-op konsekwensies vir die opleiding hieruit te trek nie: "Daar is heelwat deskundiges wat meen dat dic ideale voorbcrciding vir topbestuur 'n universitêre loophaan is waarin kursusse in dic gcesteswetenskappe en die wysbegeerte ook ingesluit word. Die doel van hierdie studierigtings is nie om die brein met feite vol te prop nie, maar om die student te leer hoe om sy intellek te gebruik, om intellcktucle nuuskierigheid, verbeelding en morele standvastigheid te ont wikkel. Dit kan gestel word dat kursusse van hierdie aard geen direkte beroepswaarde het nie. Maar dat hul nogtans bydra om die intellek en oordeelsvermoë te verryk, kan nie betwis word nie. Hierdic verryking kan nie deur spesialisasie bekom word nie".

Daar is dus dric algemene faktore wat 'n kern van basiesc opleiding in enige universitêre bcroepsopleiding of voorbereiding vereis: (i) die snelle ont wikkeling op tegniese gebied, (ii) die belangrike rol van kreatiewe denke en (iii) die groeiende administraticwe verantwoordelikheid van die bcroepsbeoefenaar. Dat stemme begin opgaan vir 'n fusie van beroepsopleiding met akademiese opleiding in ooreenstemming met Whitehead sc slagsin: "There can be no adequate technical education which is not liberal and no liberal education which is not technical" (vgl. Bushnell 1967:201), hoef ons dus nie te vecl te verbaas nie.

\section{FILOSOFIE IN ENKEI,F BEROEPE}

Die tipering wat tot dusver van die berocpsituasie gegere is, is cgter te algemeen cn onomlynd om werklik 'n presicse aauduidiug van dic belang van Filosofie en vakfilosolic in beroepskonteks te gec. Daarom wil ck graag dic aandag vestig op spesifieke beroepsprobleme waarin daar 'n sterk wysgerige en/of lewensbeskoulike komponent is, sodat daaruit die betckenis van die Filosofie (en vakfilosofie) vir beroepe, die van (sake)bestuurder en geneesheer, (arbitrêr) gekies, in dic hoop dat dic leser self analogieë in andler beroepe mag vind. (Ek wil geredelik toegce dat my gevolgtrekkings deur die aard en hoeveelheid gekose berocpe ernstig gerelativeer mag word.)

\section{DIE (SAKE)BFSTUURDER}

Die bestuurder van 'n groot maatskappy bevind lom vandag in 'n mocilike. posisie. Soos ons reeds uit dr. Jacobsz se opmerkings kon agterkom, is hy dikwels dic "produk" van 'n berocpstegniese opleidling, en as hy so gelukkig is dat hy in 'n fakultcit van ekonomiese wetenskappe opgelei is, dan heel moontlik met behulp van 'n teoreticse model wat nie genoegsaam rekening hou met die veranderde realiteite waarmee hy in die werksituasie te make kry nie. 
Dic ou ckonomic-lilosofic wat op Adam Smith se geloof in dic harmonic̈ring van eiebclang in die mark gebascer was, Malthus se teorie dat die verhouding tussen die bevolkingsaanwas en dir toename in voedselproduksie sodanig is rlat die arbeider altyd op die bestaansvlak sal bly, R icardo se ystere loonwet waarvolgens die arbeider ook nic meer as sy barre hestaansvoorwaardes kan verdicn nie, en die sosiale Darwinisnce van Herbert Spencer wat slegs die sterkere in die ckonomiese wêrcld oorlewingskans gun (vgl. Selekman, 1959:6 e.v.), het sy geldigheid verloor omdat die klassiek kapitalistiese ckonomiesc stelsel vervang is en word deur 'n welvaartsamelewing waarin heelparty ander faktore ook nog 'n rol speel.

In die eerste plek, hoe sterk die idille van die vrye mark ons ook al mag bekoor, in die werklikheid bestaan dit nie meer nie. Die markplek het 'n operasieveld van magslaktore geword wat die best uurder met geweldige groot verantwoordelikhede belas. Ons hoef slegs te wys op die mag van kommunikasic deur advertensieveldtogte en borgskappe, die mag van organisasic deur kartelvorming en die reaksie daarop deur konsumenteorganisasies, die invloed van die regering (onder of sonder politieke druk van die bevolking) deur begroting, loon- en prysbehcer, ensovoorts (vgl. verder Petit, 1967:12).

As dic bestuurder dan 'n hö̈ suil in die botsing of samewerking of sameswering van magte geword het en hy self oor die magte van organisasic, kommunikasic, tegniek, wetenskap en kapitaal beskik, maak dit nie 'n wysgerige besinning op die sin en verantwoordelike uitoefening van mag gebiedend noodsaaklik nie? En sou vakfilosofiese besinning oor die wese van die besondere magte - van belang is hier sosiale filosolie, filosolie van tegniek, wetenskapslecr en lilosofic van die ckonomiese - nie 'n rigtinggewende bydrae kon lewer tul die verantwoordelike optrede wat van 'n bestuurder verwag word nic?

Die skeiding wat in groot maatskappye tussen rienaar en bestuurder tot stand gekom het, het die druk vau die eiebelangmoticf in die bedryl iet wat versag. Die lestuurders laat hulle deesdae ook deur ander oorwegings as suiwere winsmaksimering lei: as die onderneming dueltreffend en meedingend produseer, blyk die meerderheid bestuurders bereid om 'n decl van hulle wins op te offer vir die prestige van die maatskappy en via sosiale voorsienings ook vir die vooruitgang van die personeel (vgl. verder Petit, 1967:9 e.v.). Dit bring mee dat die berlyf' 'n versorgende rol naas die van ekonomiese produksie aanneem, waardeur dic bestuurder in 'n omvaltender soort voogdyskapsverhouding tol sy personecl te staan $\mathrm{kom}$. 


\section{Venter}

Maar hiermee word 'n nuwe dimensie aan die geregtigheiclsvraag ten opsigte van die bedryfslewe toegeken: dit gaan nou nie meer slegs om 'n behoorlike beloning vir gelewerde dienste nie maar ook om die reg al dan nie op die handhawing van 'n verworwe lewenstandaard, arbeidsomstandighede, versorging in geval van liggaamlike ongeskiktheid, beskerming teen korrupte gesagsuitoefening deur meerderes, ens. Nie alleen die wysgerige geregtigheidsvraag is hiermee in geding nie, ook die hele problematiek van 'n menswaardige bestaan.

Verder: doelereffende gebruik van organisatoriese mag deur die werknerners het die geloof dat dit onvermy delik en goed is dat die arbeider in die knellinge van 'n bestaansloon vasgevang word, verlede tyd laat word: hy beding vir hom hoër vergoeding en beter versorging. Dit plaas die besluurder egter in die onderhandelingsposisie, waarin ondernemingsbelang, werknemersbelang en landsbelang teen mekaar nitgeweeg moet word. Meer nog, omdat soveel vir die werknemer van 'n gesonde werksituasie afhang - sinvolle arbeid, die brood van sy gesin, mediese en oudagsversorging ens. - eis hy steeds meer inspraak in die beleid van die lirma (vgl. ook Van der Ven, 1966:154 e.v.) en stel die bestuurder so in die situasie dat hy sy gesag en die van die aandeelhouers moet legitimeer en ook die grense en verspreibaarheid daarvan erken.

Dit lyk my dat ons hiermee voor die problematiek van die onderlinge verhoudinge in die bedryl, veral die van gesag en demokratisering, te staan kom en onafwendlbaar teruggestuur word na die sosiaal-filosofiese bodems van ous bestuurstenke.

Barre "survival of the littest" in die ekonomiese sfeer durf min mense nog te preek. I)ie prolsleem van st unkturele werkloosheid, die vraag na die sinvolle besighou van mense, die insig in die verband tussen werkloosheid en kriminaliteit dwing ons om die swakker arbeider nog in diens te hou, om die werklose finansieel en andersins te ondersteun, om die swakker bedryfistak te subsidieer. Dic bestumrder is koördineerder van personeel, materiaal en kapilaal om daaruit 'n doeltreffend lunksionerende bedryf te bou.

Het dit nie lyd geword dat hy gedwing word tot sistematiese besinning oor die grondverhouding tussen die elemente wat hy moet koördineer nie? Kan in hierdie verband die vraagstuk na die wese en waarte van menslike arbeid in 'n tyd van groeiende outomatisering en korter wordende werksweke onl wyk word?' (Vgl. verder (iondzwaard, 1967: 160 e.v.) Huiwer ons nie met hierdie vrae op die grense lussen wysgerige antropologie en vakfilosoliese 
besinning op die ekonomiese werklikheid nie? Die produktiewe arbeidstyd van die werknemer is tog nie van sy opleiding, vrye tydsbesteding, aftrede en sterwe geskei nie!

Die bestuurder gee leiding aan 'n samelewingsverband wat geweldige invloede op ander verbande in sy omgewing uitoefen: botgskappe vir sporten kulturele aktiwiteitc, linansiële ondersteuning aan opvoedingsinstellings, buurtontwikkeling en buurtversteuring, druk op die regering, ensovoorts (vgl. hieroor Petit, 1967:8 e.v., en 9 e.v.). Behoort die bestuurder, wat in hierdie konteks 'n beslissende verantwoordelikheid dra, dan nie met die vraagstukke van die wysgerige samele wingsleer gekonfronteer te word nie? Sy besluitvorming raak immers die verhouding tussen bedryfen gesin, skool, universiteit, staat, sportverenigings ensovoorts. Van besondere belang vir ons is die probleem van die verhouding tussen bediyf en universiteit, omdat hulle besonder nou met mekaar verweet word deur ons tegnies-wetenskaplike kultuur - die finansiële versoeke van die universiteite word al hoe hoër en clie belang van die bedryf in die universit eit op grond van sy bydrae steeds groter (Esterhuyse, 1977:269). Dit kan ook tot die voordeel van die beroepsopleidende dosent dien indien die bediyfsbestuur 'n verantwoorde insig in akademiese vryheid het.

Saamgevat: die bestuurder is 'n gesagsdraer met 'n geweldige potensiële invloed op sy kulturele omgewing (skool, universiteit, politieke bestel, mark) en 'n uitgebreide verantwoordingsplig (teenoor aandeelhouers, werknemers, koperspubliek, regering). Slegs 'n uitnemend bevooroordeelde persoon kan ontken dat 'n Christelik wysgerige visie op die mens, die samelewing, die bedryf, die tegniek, die ekonomie, die arbeid ensovoorts nie 'n besondere betekenis vir sy werk kan lıê nie en dus nie in sy opleiding ingesluit behoort te word nie.

\section{DIE (;ENEESHEER}

Ook die arts se situasie het in die afgelope eeu drasties verander en onıvattend geword - van hom word veel meer verwag as net die toepassing van lsepaalde geneeskundige tegnieke onder gelding van sy professionele kotle.

In teenstelling met die tradisionele opvatting, stammend van Hippokrates, dat die arts hom slegs met die geneeslike sieke besig hou, stel De Froe (1969:25) die posisie van die hedendaagse geneesheer soos volg: "Tegenwoordig weten wij dat voor die ongneeslijke vakkundige bijstand onmisbaar 


\section{Venter}

is; cr zijn geen zieken voor wie wij niets kunnen doen. Daar komt nog iets bij: wij beperken onze luulp niet langer tot alleen maar de zieken. De erfelijkheidsleer bcmoeit zich met de gezonde overdragers van de erfelijke zickten; de voedingsleer houdt zich bezig met - soms gezonde - mensen die door ondervoeding worden bedreigd. Onze bemoeienis laat haast niemand meer met rust. Wij dringen huizen binnen om ongedierten te verdelgen, stellen eisen - soms tevergeefs - aan woninglouw, riolering, waterleiding, verlichting, enz." Aan hicrdie omvaltende taakstelling vir die mediese professie word 'n waarskuwing toegevocg - waarskuwing wat dic kulturele en wysgerige wortcls van die mediese problematick direk voor ö̈ bring: "Dit mag alles lofwaardig zijn... maar het maant tevens tot voorzichtigheid: Wij moeten oppassen voor de overmoed. Om deze overmoed te betcugelen dienen wij steeds in ons medisch denken en doen de vraag te betrekken: hoe ontkomen wij aan de dreiging van onze vooruitgang?"' (1969, 26). Kortom: oor dic medikus se omvattende en prestasieryke besig wees met die hcle samelewing val 'n skaduwee - dié van 'n bepaalde magteloosheid teenoor die vooruitgang in mediese mag. Net soos die bestuurder sit die dokter met 'n magsproblecm, en die verskuiwing van onmag na mag bring die wysgerige dieptevrac van die mediese etiek na vore. Hierby hoort vrae aangaande die instandhouding van 'n lewe wat nie meer lewenswaardig lyk nie (die eutanasievraagstuk), oor die keuse tussen menselewens (in aborsie, byvoorbceld), aangaande die uit weeg van suksuele moraliteit teen ongewenste swangerskap (die antikonsepsicprobleem).

Van den Berg (die metabletikus) bekla hom dat in die mediese opleiding "dle zieke, lijdende, stervende mens, de mens die worstelt met problcmen van urbanisatie, specialisatic, vereenzaming, veroudering, kortom de mens in zijn strijd met zijn menselijk tekort" nie die nodige aandag ontvang nie. As medici weinig hieroor te sê het, wysgere stel belang! Die gebrek aan wysgerige onderlegdheid in die mediese lakulteit is miskien een van die verklaringsgronde vir die terughoudendheid van mediese wetenskaplikes oor hierdie vrae. Want hoc kan ons dic eutanasie-, aborsie- en antikonsepsieprobleme aanpak sonder dic grondraamwerk van 'n wysgerige (ol ontwikkcld lewensbeskoulike) antropologic? En hoe kan ons kultureel vasgclegde voedingspatrone, finansicel en esteties bcpaalde woninginriging medies aanpak en verander sonder 'n wysgerige (en/of lewensbeskoulike) perspektief op die samehang van die determinante van kultuur, kunssin en beskikbare geld (ensovoorts) binne die grense van 'n mensegenteenskap of'n individuele lewe? 
Filosofie en bernepsopleiding

Die gestelde problematick word verder verkraaines wanneer ons dit vanuit die verhouding tussen arts en pasiënt beskou. Dic vrocëre konsipiëring van hierdie verhouding was tegnokraties: rlie arts spreek vanuit sy mecrdere kennis, en die pasiênt volg die arlvies op gesag van deskundigheid van die arts. Teenswoordig vind egter'n verskuiwing plaas: $1 \mathrm{cn}$ spyte daarvan dat sy deskundigheid tcen 'n loë tempo toeneem, neem die gesag van dic arts in 'n sekere $\sin$ af (as gevolg van die emansipasie van allerlei saınclewingssektore) en kom hy toenemend in 'n kollegialiteitsverhouding tot sy pasiënt te staan. In navolging van Freud gaan sommige sells uit van die outonomie van dic pasiënt en trek die gevolgc hiervan op terapeutiesc gebied deur, byvoorbceld deur die toelating van jeugmisdadige gedrag omdat dit psigiatries gesonde gevolge sou hê, of op dic gebicde van antikonscpsic, abortus cn culanasie (vgl. hieroor Musaph, 1969:1 I5 c.v.). Ook al verwerp ons dic tegnokratiese standpunt, dan is dit nog stecds belangrik onn die vraagstuk van die gesag van die genceshecr in beskouing te neem in verband met die norme wat vir die verhouding I ussen dokter en pasiënt geld. Want die pasiënt kan in sy (gewaande) outonomie aandring op enigicts van 'n onnodige medisynevoorskrif tot die toepassing van genadedood (vgl. ook Van (len Berg, 1969:5).

Ook die vraagstuk van die verhouding tussen gencesheer en samelewing is wysgrrig belangrik. Dic dokter is 'n professioncle man wie sc opticde teenoor sy pasiënte veral deur 'n professionele kode geteguleer word. Hy word egter nic uitsluillik deur altrüstiese professionele dicnsmotiewe gemotiveer nic: die mag van organisasic is recds deur die mediese beroep to sy cic voordecl ingespan. In dic afyelope paar jaar het ous herlaalde proteste teen politieke belieer oor mediesc tariewe uit die kring van georganiseerde genceshere mocs aanhoor (jammer genoeg gepaard met'n totale swye oor die reguerdigbaarheid van die georganiscerde berocpskartelvorming wat die politieke inmenging uitgelok het). Dit bring ons (erug by die dieper wysgerige vraag na die verlouding tussen algemene belang, ciebelang on diensmotief. Miskien kan ons nog daarin slaag om die betekenis van die. Christelike rentmeesterskapmoticl ook vir hierdie professic duidelik te maak.

Wat beteken dit alles vir die opleiding van 'n medikus?' Van den Berg (1969:11) pleit vir wat hy norm 'n "integrale genceskundige opleidling" wat met die volle beslaan van die mens rekening hous. Kan so 'n oplciding werklik sonder eksplisiete wetenskaplike aandag aan lewens- en wêreldbeskoulike vraagstukke tot stand kom? Kan die vraagstukke van lewe en dood indringend behandel word sonder om die wysgerig antropologiese 


\section{Venter}

biolilosofiest, psigofilosoliese en sosiaal-filosofiese wortels eksplisiet te maak? Indien reg gerapporteer, dan het ook dr. J. Saunders, Vise-Kanselier van die Universiteit Kaapstad, aspekte van die onderhawige probleem raakgesien. Volgens die Daily Dispatch (82-04-26:5) het hy hom op 24 April 1982, in 'n toespraak waarin onder andere ook die sosiale verant woordelikheid van die geneesheer ter sprake gebring is, soos volg oor die opleiding van geneeshere in 'n eell van vooruit gang op die gelied van mediese tegnologie uit gelaat: "It seems to me that we must broaden the base of our educational system. We should at least insist that medical students choose from one of a group of subjects, such as history, or a language or philosophy. (ne should try to ensure that this happens by removing somet hing from the curriculum, which is already too crowded and compressed".

\section{ENKEIA UITLOPHRS}

Hoewel my argument gerelativeer word deur die keuse van beroepe wat bespreek is, meen ek tog dat die belangrikste wat ten opsigte van hierdie beroepe uitgewys is, mutatis mutandis ook vir alle ander beroeje kan geld. Beroepsmense is immers besig met 'n gespesialiseerde vorm van kulumurbeoefening in 'n sannelewingskonteks en mag dus altyd met die vraagstuk van verant woordelike beroepsuitoefening gekonlronteer word. I)aarom mag ons van hulle verwag om perspektiewe te vorm oor die grondsa mehange waarin hulle moet funksioneer - 'n perspektiefvorming waarin die Filosolie 'n belangrike rol het om te speel.

()ns moet egter, indien ons daarin kan slaag om ons kollegas in die berocpsopleidingsrigtings te oortuig dat die beroepswêreld wemel van die wysgerige vraagstukke, nie te vanselfsprekend aanneem dat hulle dan ook bereid gaan wees om f'ilosofie en vaklilosolie in hulle leergange op te neem nie. I Jie opdraand is steiler as wat ons vermoed.

'T'en ecrste sit hierdie dosente met die probleem van oorvol leergange dikwels gebaseer op vecleisende voorskrifte van professionele (hv. mediese en prokureurs-) verenigings en ander organisasies (werkgewers-, kerklike sinodes, ens.) wat toelating tot die betrokke beroepe beheer. Die oortuigingswerk moel dus ook na invloedrykes in die beroepswêreld uitgebrei word. (iesien die besinning wat alreeds in daardie geledere plaasvind mag ons daar 'n mate van welslac behaal, maar waar word rilosolie en vaklilosolie dan in die leergang ingepas? Ons kan dr. Saunders se taad volg en probece om iets uit die bestaande leergang te laat verwyder, maar wie gaaıı bly wees as sy vak of spesialiteil vir die Filosofie moet plek maak? 
Filosofie en beroepsopleiding

Ten tweede mag ons nie vergeet dat wysgerige vraagstukke fundamenteel en daarom omstrede van aard is. Die neiging is om eerder self, al is dit dan amateuragtig, dic omstrede sake met studente op te neem as om toe te laat dat die student deur die "aweregse" ideë van die filosowe "verwar" word. As die prolessor in Ginekologie radikaal van die professor in Filosolie verskil oor die vraagstuk van abortus na verkragting of voorbehoedmiddels vir ongetroudes, kan hy dalk verkies om "sy" studente te "beskerm" teen die "verderflike" invloed van die filosoof.

Derdens is dit ernstig die vraag of ons as filosowe en vakfilosowe wel in die verlede genoegsaam getoon het dat ons doeltreffend binne die soort konteks wat deur beroepsopleiding vereis word, kan funksioneer. Kan ons byvoorbeeld 'n eenjarige Wysbegeertekursus so inrig dat die beroepsgerigte student die nodige vir sy beroep claaruit kan put? Of is ons, die wysgere - wie se roeping dit is om die uitsigverskaffers in 'n eeu van vakspesialisme te wees -dalk self so aan ons eie spesialismes verknog dal ons die grense na belangrikleid nie meer kan oorbrug nie? Sal ons daarin kan slaag om die integriteit vals ons vak te behou sonder om vir almal wat in ons klaskamers verskyn, alles van Thales tot Marcuse en van Kuyper tol Seerveld te leer? En het ons al geleer om in so 'n konteks ons wysgerige krit iek so te lewer dat ons nie ons - bowendien bevooroordeelde en daarom oorgevoelige kollegas van ons vervreem nie? Het ons al geleer om te begin met iemand se voete te was eerder as onmiddellik sy kop te was oor al die heidense vooronderstellings wat hy onwetend saam met sy vakkennis deurgee?

Wat ons as ' 11 wegspringplek nodig het, meen ek, is 'n interdissiplinêre aanpak wat filosoof, vakfilosoof, vakwetenskaplike en ervare beroepsmense saam betrek in die totstandbringing van beroepsfilosofiese hooflyne wat 'n ecrstejaarsprogram kan dek, eerder as om te verwag dat die beroepsgerigte studente ons algemene filosofiekursussc ongewysig moet neem. Ons staan dus voor die moeilike taak om van toegepaste na basiese Filosofie te beweeg in plaas van andersom. Durf ons dit op hierdic wyse aan, staan ons moontlik 'n kans om berocpsopleiers, beroepsuitoefenaars en beroepsgerigte studente almal vir ons vak te interesseer en - wie weet - 'n paar studente so gaande te maak clat hulle dalk met filosofie wil voortgaan.

Verder het ons 'n simpatieke universiteitsowerheid nodig wat bereid is om met die beroepswêreld, die professionele verenigings, die kerke ensovoorts in gesprek te tree oor die eise wat hulle aan die universitêre leergange stel. Hierdie eise kom die universiteitsopleiding as geheel, maar ook die wysgerige opleiding in die besonder, dikwels te na. Wanneer 'n professionele 


\section{Venter}

vereniging tot op die aantal lesure presies voorskryf wat en hoeveel aandag 'n student aan 'n bepaalde onderwerp moct wy, word die prinsipiële besinning uit daardie opleidingsgebied (nog ten spyte van en ongeag die prinsipiële uitgangspunte van die betrokke universiteit) uitgeban. En wanneer ' $n$ sinode voorskryl dat sy aanstaande predikantc in 'n Wysbegecrte I-kursus die hele geskiedenis van die Filosofie moet insluk - die term "Ieer" is hier onbruikbaar - , word die wese van Filosofie as vak, sy betekenis vir die Teologie en die betekenis van Wysbegeertegeskiedenis binne die geheel van die Filosolielcerplan geheel en al misken. Hierdie soort eise misken die soewcreiniteit in cie kring van die universiteit, daarom behoort nie-universitêre instansies hulle lecrgangvereistes slegs in oorleg met die universiteitsowerhede vas te stel, en die universiteitsowerhede behoort daarop aan te dring dat hulle gesag in hierdie verband erken word.

Die Filosofie en verskillende vakfilosoficë kan hullc eie posisic versterk deur beroepsonderskragend te werk. Belangrik is in hierdic verband om verwaarloosde of onderontwikkelde beroepe deur 'n beroepsfilosolie te ondersteun. Ons scientisties-tegnologies-utilistiese samelewing trek die berocpc wat gebruiksnut het, vóór; kunstenaars, kunsonderwysers, predikante, kultuurleiers, volkekundiges raak stceds meer vergete. Dit is die taak van die filosoof - self bedreig deur berocpsvergetelheid - om aan die beleidmakers duidelik te maak dat dit nie mannekragvermorsing is om iemand as kunstenaar of predikant of filosoof op te lei nie. ' $n$ Samelewing het mecr nodig as net boere, ingenieurs en sakemanne, selfs as clit van brood, spele en televisie alleen wil lecf?

Kan ons daarin slaag om interdissiplinewerkgroepe te vorm, die universiteitsowerheid se simpatie te kry, nog 'n hand te reik na vergete berocpe? Maklik seker nie, maar selfverloëning, bereidheid om vermaning te aanvaar en op die regte wyse te gee, ondersteuning met liefde te gec, vermag veel, veral as hulle binne die akademiese gemeenskap van die heiliges uitgeleef word.

\section{LITERATUURLYS}

BОТНА, M.E. 1979. Filosolie, vakwetenskappe en grondslacondersoek. Koers, 44:421-259.

B()THA, M.E. 1980. I)ie bevordering van geesteswetenskaplike studie. Koers, 45:103-120.

BUSHINELL, D.S. 1967. The valuc of vocational education. (In. $\mathrm{R} \Lambda$ Gordon ed.) Toward a manpower policy. New York: John Wilcy: 193-214.) 


\section{Filosofie en beroepsopleiding}

DE FROE, $\Lambda$. 1969. Medische ethick moct democratish zijn. (In Calff, J.P. red.) Medische ethick vandaag, Amstcrdam: Agon Elsevicr:23-32.) DE LANGE, S.A. 1969. Diagnostiek van de dood. (In Calff J.P. red) Medische ethick vandaag, $\Lambda$ msterdam: $\Lambda$ gon Flscvier:87-94.)

DU PIESSSIS, P.G.W. 1969-70. Wysbegecrte, kultuur en toekoms, in: Koers, 37, 1969-70, 274-283.

DURKHEIM, E. 1957. Professional ethics and civic morals, tr. by C Brookfield. London: $\mathrm{R}$ \& $\mathrm{K} \mathrm{P}$.

ESTERHUYSE, W.P. 1974. Wetenskap, waardevryheid en verantwoordelikheid. Perspeklief 13(2+3):18-29.

ESTERHUYSE, W.P. 1975. Wetenskap en maatskappy. Johannesburg: RAU (Publikasierceks B6).

ESTERJUYSE, W.P. 1977. Future perspectives on the university and the community, in: Koers, 42(4), 1977, 258-273.

GARBERS, J.C. 1980. Dic universite it en beroepsopleicling. Koers, 45:93-102. GARDNER, J.B. 1981. Some observations on the responsibility of the university to the prolessions. Alice: Fort Hare. Univ. Press.

GINZBER (; E. 1971. Manpower for development, New York:Pracger.

GOUDZWAARD, B. 1976. Kapitalisme en voortuitgang, Assen:Van Gorcum.

HÄRING, B. 1972. Medical ethics. Slough: Sı Paul Publications.

HRSC. 1981. Provision of education in the RSA. Report of the Main Committec of the HRSC: investigation into Education, Pretoria: HRSC.

JACYOBS\%, F.P. 1977. Dic aanspraak van die beroepswêreld op die universitcit (In UPE. Die uitclaging aan dic moderne universiteit, Port Elizal)eth, UPE:21-31.)

JOHNSON, 'I.J. 1972. Prolessions and power. I ondon: Macmillan.

KERR, C. 1963. The uses of the university, Cambridge (Mass.):Harvard UP.

KLOOSTERMAN, G.J. 1969. Abortus provocatus: wel liberaliscren, niet vrijlaten. (In CalfT.J.P. red. Medische ethiek vandaag Amsterdam: Agon Elsevier:61-72.)

MUSAPH, H. 1969. De verhouding arts-patiönt-van vertikaal naar horizontaal. (In: Calf, J.P. red. Mrdische cthick vandaag. Amsterdam: Agon Elsevicr: 113-120.)

PEIIT, T.A. 1967. The moral crisis in management New York:McGraw-Hill.

POI.AK, B.S. 1969. De huisarts en de waarheid. (In Callf.J.P. red. Medische ethiek vandaag, Amsterdam: Agon Elsevier:121-128.)

PRASAI), S.B. ed. 1967. Management in international perspective. New York: $\Lambda$ ppleton-Century-Crofts. 


\section{Venter}

RAU. 1973a. Die taak van die RAU as stadsuniversiteit. Johannesburg: RAU.

RAU. 19731. Vernuwing in die universiteit in die jare 70 en 80. Johannesburg: RAU

ROBBER'ISE, W.P. 1980. Suid-Afrika se dilemma: uitdagings en geleenthede. hoers, 45:121-142.

SCHUURMAN, E. 1977. T'echniek: Middel ol Moloch. Kampen:Kok. SELEKMAN, B.M. 1959. A moral philosophy for management. New York: Mcliraw-Hill.

SIMON, H.A. 1960. 'The new science of managenent decision. New York: Harper \& Row.

SIMON, H.A. 1961. Administrative behavior. New York: Macmillan. SPILS, M. 1979. Die bydrae van werkgeleentheidskepping tot die ekonomiese ont wikkeling van Kwazulu. Kwa-I langezwa: Univ. van Zoeloeland. 'I'REFIPERS, P.E. 1969. Vrije abortus - slordige anticonceptic. (In Calff J.P. Red. Medische ethiek vandaag. Amsterdam:Agon/Elsevier: 129-139.) TYLER, R.W. 1972. More eflective education for the prolessions. (In Berg, I. ed. Human resources and economic wellare, New York: columbia UP:220-240.)

UNESC:O. 1963. Energy and skills for human progress, New York: Oceana Publications.

VAN IDEN BERG, J.H. 1969. Verworven medische macht vraagt naat vernieuwing van elhiek. (In Calff, J.P. red. Medische ethek vandaag, Amsterdam: Agon Elsevier: 1-12.)

VAN IUER VEN, I'J.H.M. 1955. Bedrijfsleven en democratie: Leiden: Stenfert Kroese.

VAN RIESSEN, H. 1971. Mondigheid en de machten. Amsterdam: Buijten of Schipperheijn.

VENTER, J.J. 1975. Yesterday and today; the task of the university. Koers, 40: 402-420.

VENTER, J.J. 1977. Die universiteit en die toekoms. Perspehtief, 16 (2, 3):73-99.

VEN'I'ER, J.J. 1978. Akademie en politiek. Körs, 43:317-330.

WIBAUT', I.P. 1969. De huisarts mag geen zedenmeester zijn. (In CallI J.P. red. Medische ethiek vandaag. Amsterdam:Agon Elsevier: 149-156.) 